\title{
USE OF THE BACTERIUM SERRATIA ENTOMOPHILA FOR CONTROL OF GRASS GRUB IN LAWNS
}

\author{
T.A. JACKSON, J.F. PEARSON and R.J. TOWNSEND
}

\author{
AgResearch, PO Box 60, Lincoln
}

\begin{abstract}
The bacterium Serratia entomophila, cause of amber disease in grass grub (Costelytra zealandica), was tested to determine its potential as a biocontrol agent for protection of lawn turf from grass grub attack. Pots containing lawn turf and introduced grass grub were treated with bacteria applied by surface application or by soaking roots in bacterial suspension before planting. The bacterial treatments maintained vigour of the turf, reduced grass grub populations and resulted in amber disease in $79 \%$ of the remaining larvae. Four home lawns, naturally infested with grass grub, were treated with bacteria in a water drench. Sampling one month after treatment confirmed establishment of the applied strain, S. entomophila 154, and indicated an average of $46 \%$ amber disease among grass grub larvae in the treated lawns. These trials demonstrated that $S$. entomophila can establish, infect grass grub larvae and reduce damage when applied to lawn turf.
\end{abstract}

Keywords: Grass grub, Costelytra zealandica, Serratia entomophila, amber disease, lawn turf.

\section{INTRODUCTION}

Grass grub (Costelytra zealandica White) is one of New Zealand's most important pasture pests (Garnham and Barlow 1993), and is also recognised by homeowners and urban park managers as a cause of damage to amenity and recreational turf. In the past, persistent chemicals were the main defence against grass grub and other garden pests and little thought was given to their residues around the home. With increasing awareness of chemical residues, persistent organochlorine insecticides have been replaced by more transient chemicals, but toxicity and residues remain important issues.

Over the past decade, biological control has been emphasised as the preferred option for pasture pest management and some of the technologies developed may also be appropriate for use in the urban setting. The bacterium Serratia entomophila, marketed as the commercial biocontrol product Invade, has been used for grass grub control in pastures for almost a decade. For protection of pastures, a bacterial suspension is injected into the soil using a modified seed drill and the applied bacteria establish a cycle of amber disease in the treated grass grub population, reducing both the pest population and level of pasture damage (Jackson et al. 1992). Use of a large seed drill, however, is not appropriate for urban lawns and use of a simple drench application was investigated. Two experiments were carried out to determine whether the bacterium could be used to reduce the grass grub problem in lawns. The first was a small outdoor pot trial to investigate whether the application of bacteria could prevent damage to lawn turf grasses. In the second experiment, bacteria were applied to natural populations of grass grub in home lawns.

\section{Bacteria}

\section{METHODS}

The commercially available product Invade, a bacterial suspension containing $>4$ $x 10^{13}$ S. entomophila (strain 154) per litre was used in the lawn trials. Invade was manufactured by Industrial Research Ltd., Lower Hutt on January 21st 1999 and stored at $4^{\circ} \mathrm{C}$ until use. 


\section{Pot trial}

Sections of PVC culvert pipe (300 mm internal diameter, $250 \mathrm{~mm}$ in length) were placed vertically on a bed of sand. Tubes were then filled with sieved Templeton silt loam soil to $70-80 \mathrm{~mm}$ below the rim. Thirty-eight, healthy, early $3^{\text {rd }}$ instar grass grub larvae (average weight $0.158 \mathrm{~g}$ ), collected from the AgResearch Lincoln farm, were added to each tube and allowed to burrow into the soil. A circle of 1-year-old lawn turf, composed of a browntop/red fescue mix (Agrotis tenuis Sibth./Festuca rubra L.) (Prebble's Turf World, Christchurch), approximately $50 \mathrm{~mm}$ thick with a $25 \%$ moisture content, was cut accurately to fit in the top of the tube. Bacteria in the drench application were applied by watering can with $0.1 \mathrm{ml}$ of bacterial suspension in 1 litre of water (an application rate of approximately $6 \times 10^{10}$ bacteria $/ \mathrm{m}^{2}$ ) and washed into the surface with a second litre of water. For the soak treatment, turf was placed in a $1 \%$ bacterial suspension for five minutes resulting in the absorption of $600 \mathrm{ml}$ of suspension per turf producing an application rate of $2 \times 10^{12}$ bacteria $/ \mathrm{m}^{2}$ followed by a surface drench with 1 litre of water. Control sections of turf were drenched with 2 litres of water (equivalent to $28 \mathrm{~mm}$ rain). The trial layout was completely randomised with 8 replicates of each treatment. Treatments were applied on March 22nd 1999, in warm conditions, and the tubes were subsequently watered as needed to maintain the soil moisture at approximately $20 \%$, sufficient for turf establishment. Turf vigour was visually assessed after seven weeks by scoring each plot for growth (scale $1-5$, where $1=$ poor vigour and $5=$ vigorous growth) by eight independent observers. Following this assessment, four replicates from each treatment were destructively sampled for estimation of level of disease and grass grub survival. Larvae showing a clear gut typical of amber disease were classified as diseased (Jackson et al. 1993). Disease was reassessed after a 3 day feeding period to provide a more accurate estimate of percentage infected (Townsend 1998). Data were statistically analysed using analysis of variance.

\section{Application to lawns}

Areas of lawn showing evidence of grass grub attack in the suburb of Halswell, Christchurch, were selected for application of Invade in 1998 and 1999. Two lawns were treated in each year. The lawns showed typical patchy damage with larval density in the damage patches estimated at $>200 / \mathrm{m}^{2}$. Larvae were collected from the damaged lawns at each site prior to application and examined for visual symptoms of disease. S. entomophila was applied (Table 2) as a soil drench through a watering can to prewatered damaged lawns ranging in size from 50 to $275 \mathrm{~m}^{2}$. The application rate $\left(4 \times 10^{10}\right.$ bacteria $/ \mathrm{m}^{2}$ ) was equivalent to 10 times the normal commercial application rate to pasture. A light watering of $5 \mathrm{~mm}$ followed application. At each site, a second similar area of lawn was selected as an untreated comparison. Approximately one month after treatment, each site was sampled and 20-30 larvae were collected and taken to the laboratory for disease assessment. At least five soil samples of approximately $100 \mathrm{~g}$ were taken from treated and untreated areas to a depth of 70-80 mm and mixed together as a pooled site sample. Serratia spp. bacteria from these samples were quantified and identified using the method of O'Callaghan and Jackson (1993a) and further phage typed to enable identification of the applied strain (O'Callaghan and Jackson 1993b).

\section{Pot trial}

\section{RESULTS}

After seven weeks, clear visual differences were evident between treatments. Both bacterial treatments were producing vigorous turf with assessment scores significantly $(\mathrm{P}<0.05)$ higher than the untreated turf (Table 1) which showed less growth and yellowing of the tillers. Turf in the untreated plots had poor root growth compared to turf treated with bacteria, which had extensive nodal roots extending down to the sand bed at $220 \mathrm{~mm}$ depth. Grass grub numbers were significantly $(\mathrm{P}<0.05)$ reduced following bacterial treatment (Table 1) and a mean of $79 \%$ grass grub in the S. entomophila treated plots showed symptoms of disease compared with $17 \%$ apparent disease in larvae from the untreated plots. While the soak treatment resulted in a significant $(\mathrm{P}<0.05)$ increase in turf vigour above the drench treatment, higher levels of disease were recorded from the drench treatment. 
TABLE 1: Effect of $S$. entomophila applied by soak and drench treatments on turf vigour, grass grub numbers and disease levels in a pot trial 7 weeks from application.

\begin{tabular}{lcccc}
\hline Treatment & $\begin{array}{c}\text { Mean turf } \\
\text { vigour } \\
\text { score }^{1}\end{array}$ & $\begin{array}{c}\text { Grass } \\
\text { grub } \\
\text { larvae/ } \mathrm{m}^{2}\end{array}$ & $\begin{array}{c}\text { \% disease in } \\
\text { grass grub } \\
\text { larvae }\end{array}$ & $\begin{array}{c}\text { Healthy } \\
\text { grass } \\
\text { grub/m }\end{array}$ \\
\hline S. entomophila - soak & 4.0 & 283 & 72 & 80 \\
S. entomophila - drench & 2.9 & 274 & 85 & 43 \\
Untreated & 1.8 & 375 & 17 & 316 \\
LSD (5 \%) & 0.6 & 69 & 13 & 48 \\
\hline
\end{tabular}

${ }^{1}$ Vigour score 1 = poor vigour; 5 = vigorous growth

\section{Application to lawns}

At each site the drench treatment resulted in colonisation of the soil with a mean density of $2 \times 10^{4}$ bacteria/g soil of the applied strain $S$. entomophila 154 recovered one month after application (Table 2). S. entomophila $\left(7.4 \times 10^{3} / \mathrm{g}\right.$ ) was recovered from the untreated lawn area of Site 3, while no S. entomophila was detected at other sites. A mean of $46 \%$ of larvae showing symptoms of amber disease was recovered from the treated sites. The lowest percentage disease was recorded at site 4 where there was a high proportion $(33 \%)$ of less susceptible early second instar larvae $\left(3^{\text {rd }}\right.$ instars $39 \%$ diseased). No amber disease had been observed among larvae from the treated sites prior to application and none of the untreated sites showed amber disease although protozoan diseases and milky disease were evident in both treated and untreated areas at site 4 . The visual signs of damage, thin turf and yellowing grass tillers, were rapidly reduced on the treated sites, while on the untreated check sites, grass grub damage remained evident.

TABLE 2: Bacterial numbers per gram dry soil and percentage diseased grass grub larvae, one month after application of $S$. entomophila to four lawns in Christchurch.

\begin{tabular}{clcc}
\hline Lawn & Date of application & S. entomophila/g soil & $\begin{array}{c}\text { \% diseased grass } \\
\text { grub recovered }\end{array}$ \\
\hline 1 & 28 April 1998 & $1.5 \times 10^{4}$ & 70 \\
2 & 28 April 1998 & $9.3 \times 10^{3}$ & 41 \\
3 & 16 February 1999 & $5.3 \times 10^{4}$ & 48 \\
4 & 28 March 1999 & $2.5 \times 10^{3}$ & 26 \\
\hline
\end{tabular}

\section{DISCUSSION}

Product safety, reliability and ease of use are priorities for pest control in the home environment. Biological controls, which are specific to the target pest, are ideal for meeting the first of these criteria but have not always provided consistent control following simple application procedures (Grewal 1998). In these experiments, we have applied bacteria to the soil using a simple soil drench and obtained high levels of disease among the treated grass grub larvae in all trials. Amber disease in grass grub larvae produces a rapid cessation of feeding followed by a long, chronic amber stage eventually leading to death (Jackson 1994). This cessation of feeding explains the increase in turf vigour after application and the decline in visible damage in the treated turf.

The high levels of disease obtained in these experiments suggest that the bacteria were well distributed through the soil. When bacteria are applied in drill rows, as in commercial pasture applications, disease levels are usually lower over the first month as infection is confined to larvae coming into contact with bacteria in the drill row. The 
drench treatment appeared adequate for establishment of the bacteria in the turf as bacterial density in the lawn soil one month after treatment was within $1 \log$ of the theoretical maximum density at application $\left(4 \times 10^{5} / \mathrm{g}\right)\left(\mathrm{O}^{\prime}\right.$ Callaghan 1998). The increased vigour of turf after soaking in the bacterial suspension was interesting and may have an application in preparation of new lawns with pre-cut turf.

Infection by amber disease is common among grass grub in New Zealand pastures. It is surprising, therefore, that no amber diseased grass grub larvae were recovered from the untreated lawns in this trial and the bacterium $S$. entomophila was only recovered from one site. Where naturally occurring grass grub pathogenic bacteria are lacking, we have demonstrated that fermenter-produced $S$. entomophila can be applied and will establish in lawn turf to produce amber disease infection and prevent damage by grass grub. These experiments indicate that $S$. entomophila has a good potential as a tool for grass grub management in lawn turf.

\section{ACKNOWLEDGEMENTS}

Thanks to Prebble's Turf World for providing pesticide free lawn carpet and to Dave Saville for statistical analysis.

\section{REFERENCES}

Garnham, M.L. and Barlow, N.D., 1993. Defining the cost of grass grub. Proc. 6th Australasian Grassl. Invert. Ecol. Conf.: 32-38.

Grewal, P., 1998. What killed microbial control in turfgrass? Proc. VII Internat. Coll. Invert. Path. and Micro. Contr.: 107-109.

Jackson, T.A., 1994. Effect of amber disease on the behaviour of grass grub larvae. Proc. VI Internat. Coll. Invert. Path. and Micro. Contr.: 372.

Jackson, T.A., Huger, A.M. and Glare T.R., 1993. Pathology of amber disease in the New Zealand grass grub Costelytra zealandica (Coleoptera: Scarabaeidae). J. Invert. Path. 61: 123-130.

Jackson, T.A., Pearson, J.F., O'Callaghan, M., Mahanty, H.K. and Willocks, M., 1992. Pathogen to product - development of Serratia entomophila (Enterobacteriacae) as a commercial biological control agent for the New Zealand grass grub (Costelytra zealandica). Pp. 191-198. In: Use of Pathogens in Scarab Pest Management. T.A. Jackson and T.R. Glare (Eds). Intercept, Andover.

O'Callaghan, M., 1998. Establishment of microbial control agents in the soil. Pp. 8389. In: Proc. $4^{\text {th }}$ Internat. Workshop Microbial Control of Soil Dwelling Pests. M. O'Callaghan and T.A. Jackson (Eds). AgResearch, Lincoln.

O'Callaghan, M. and Jackson, T.A., 1993a. Isolation and enumeration of Serratia entomophila - a bacterial pathogen of the New Zealand grass grub, Costelytra zealandica. J. Appl. Bacteriol. 75: 307-314.

O'Callaghan, M. and Jackson, T.A., 1993b. Bacteriophages of Serratia entomophila - a bacterial pathogen of the New Zealand grass grub. Proc. 6th Australasian Grassl. Invert. Ecol. Conf:: 399-404.

Townsend, R.J., 1998. A national survey for diseases of grass grub. Pp. 37-43. In: Proc. $4^{\text {th }}$ Internat. Workshop Microbial Control of Soil Dwelling Pests. M. O'Callaghan and T.A. Jackson (Eds). AgResearch, Lincoln. 